This is the published version of the article, made available with the permission of the publisher. The original published version can be found at the link below.

Ari Linden. (2013). Beyond Repetition: Kark Kraus's “Absolute Satire.” German Studies Review 36(3):515-536.

Published version: http://dx.doi.org/10.1353/gsr.2013.0146

Terms of Use: http://www2.ku.edu/ scholar/docs/license.shtml 


\section{Beyond Repetition: Karl Kraus's "Absolute Satire”}

Ari Linden

\section{ABSTRACT}

This article reassesses the theoretical import of the Viennese satirist Karl Kraus, arguing that his satire challenges conventional understandings of the genre. Most notably in The Last Days of Mankind (Die letzten Tage der Menschheit), Kraus's satire delegitimizes any given historical or political position, addressing, rather, what he calls "posterity" as the only viable alternative. This moment lies beyond the repetitive structures inherent to modernity, specifically as they were articulated in the First World War. Kraus's "absolute satire" (Hermann Broch) thus contains a temporal dimension insofar as its intended audience is one that does not yet exist. ${ }^{1}$

\section{Satire's Discontents}

In a 1974 lecture given in Berlin, Elias Canetti spoke about the Viennese writer Karl Kraus's "process of satire," which had exerted a significant influence on Canetti's own literary development. ${ }^{2}$ A prominent satirical author in his own right—and therefore one who could speak on the matter with some authority ${ }^{3}$ - Canetti considered Kraus a master of the form, situating him among such luminaries as Aristophanes, Juvenal, Quevedo, Swift, and Gogol. Yet Canetti had ultimately abandoned Kraus and what he called the "murderous substance" of his satire. He explained: "What annoys today's reader of the Fackel, ${ }^{4} \ldots$ is the evenness of assault. Everything happens with the same strength, everything is drawn as equally important into one and the same language . . . the victim vanishes under the incessant blows, he is long since gone, and the fight continues." ${ }^{5}$ In criticizing the way that Kraus categorically dismissed each one of his "victims" without calibrating the severity of his attacks, Canetti, I argue, raises relevant questions regarding the very "substance" of satire and its place among other twentieth-century forms of cultural critique. Is there a point at which 
satirical ridicule goes considerably too far, thus threatening to dissolve into an undifferentiated critique of any conceivable position, much like the Mephistophelian spirit "who always negates"? ${ }^{6}$ Must the satirist therefore confine his invective to this or that historical particularity? Or is there a way for satire-which, in contrast to other forms of critique, "uses laughter as a weapon, and against a butt that exists outside the work" - to be both limited and yet seemingly endless in scope? What historical conditions would produce such a satire, and what form would it take?

More contemporary critics have similarly identified immanent problems threatening satire's self-justification. In The Difference Satire Makes, Fredric Bogel writes that while satirists "often seem to be devoted to a lucid and purely oppositional singlemindedness, the shadow of connection is always there." ${ }^{8}$ In other words, contrary to its own intentions, satire, for Bogel, tends toward collusion, complicity or continuity with the object it ridicules and from which it claims to be wholly distinct. Specifically comparing Kraus's and Canetti's satirical oeuvres, Kai Evers points to the often unacknowledged complicity between the satirist and his audience. ${ }^{9}$ Evers writes, "because it is invited to identify with the power of his judgment, the Krausian audience and readership seemed to constitute a community safely grounded on shared values." ${ }^{10}$ For Evers, Kraus derives his authority from the acquiescence of his audience and from their mutual agreement on, and submission to a particular system of values. Accordingly, Kraus's satire would hardly transcend the level of "biased satire [Tendenzsatire] . . . which is bound to particular aims, loyalties and limitations,"11 if these limitations or loyalties could be understood as the system of values that allegedly binds Kraus to his audience, regardless of what these values actually are. The very fact that such a "community" has been acknowledged renders Kraus, in Evers's estimation, suspicious.

In this article I argue that none of these positions alone sufficiently grasps the substance of Krausian satire. To arrive at its proper function and telos, I will first look at Kraus's own, and often neglected speculations on satire as he articulates them in two of his seminal essays, Heine und die Folgen (Heine and the Consequences) and Nestroy und die Nachwelt (Nestroy and Posterity), before analyzing selected scenes from Kraus's dramatic lampoon of the First World War, Die letzten Tage der Menschheit: Tragödie in fünf Akten mit Vorspiel und Epilog (The Last Days of Mankind: Tragedy in Five Acts with Prologue and Epilogue). ${ }^{12}$ By combining immanent critique with a theory of repetition, I will show how Kraus's "absolute satire" (a phrase I borrow from Hermann Broch $)^{13}$ responds to both the various tensions that inhere in the satirical form as well as the accusations leveled against Kraus described above: that his night is one in which all cows are black (Canetti) ${ }^{14}$ that the satirist cannot but identify with his object of ridicule (Bogel); and that Kraus's allegedly anachronistic and normative satire relies on the "shared values" that bind him to his audience or readership (Evers). Ultimately, I argue that the figure of the Nörgler (the Grumbler) - 
who provides a running commentary throughout Die letzten Tage-represents the culmination of Krausian satire by refusing to identify with or advocate any given position, and pointing, rather, to a quasi-utopian moment beyond the present, a moment that paradoxically depends on satire's illegibility and obsolescence. Such a moment is unreadable because it has transcended what Kraus identifies as the constitutive problem of modernity: namely, repetition.

\section{Heine and Nestroy}

First published in 1910, Heine und die Folgen exerted a notoriously damaging effect on Heine's reception among a certain stratum of German (and frequently GermanJewish) intellectuals during the first half of the twentieth century..$^{15}$ Even recently, critics have attacked the essay on two significant fronts: first, for its employment of antisemitic rhetoric, which some have interpreted as an expression of Kraus's "Jewish self-hatred"; and second, for its failure to transcend the very mode of journalism that it aims to criticize. Combining this two-pronged criticism, Bernd Witte offers this formulation: "With his crude, speculative, and antisemitic literary satire, Kraus tries to separate himself from his literary Urvater (Ur-father) and give expression to his rage against the sentimental Heine-epigonism in the contemporary feuilleton. And thus he succumbs to the same mistakes as those of the journalists he attacks." 16 While I will address the second of these two objections later on, it is the first that warrants immediate attention given the historical significance of antisemitism both during and after the dissolution of the Habsburg Monarchy.

Kraus's relationship to the assimilated Jewish community in Vienna was ambiguous at best, making it difficult to determine whether his negative remarks vis-à-vis German-Jewry are simply the product of his time, or-while unpardonable on any grounds - they need to be viewed from within the perspective of his larger cultural critique. ${ }^{17}$ With regard to Heine, one is thus forced to ask if Kraus's crude and often concealed references to Heine's religion are immaterial to his critique of Heine the poet. Kraus claims that his intentions are categorically distinct from those of the völkisch, antisemitic cultural critics á la Adolf Bartels, that is, from what he refers to as the "narrow-minded hatred of Heine that aims at the Jew" but "accepts the poet ...."18 Yet while one certainly cannot rely on Kraus's self-vindication as conclusive evidence of his prejudice-free aesthetic judgment, what I would further point out in his defense is that one of the presumptions of Habsburg antisemitism (as of essentially all modern forms of antisemitism) was that so-called Jewish influence on contemporary culture - above all, on the press - was liberal in nature, modern in a bad sense, and destructive of ostensibly German values. As I will show, however, Kraus's critique of Heine is predicated precisely on the notion that the latter's explicit liberalism masked a more fundamental conservatism, that Heine's aesthetic modernism was qualitatively less radical than Goethe's and Nestroy's, and that, most importantly, 
Heine's attempts at satire did not go far enough in their destructive inclinations. Kraus can thus rightfully distinguish his position from that of the Heine admirers as well as the detractors because both camps either celebrate or denigrate the very features of Heine's writing that Kraus denies are there in the first place. To be sure: one need not endorse Kraus's conclusions about Heine in particular (and I do not) in order to understand his structural critique and the implications it contains for his theory of satire. ${ }^{19}$

According to Kraus, Heine is responsible for having produced what Edward Timms calls a "journalistic civilization" in which the distinction between literature and reportage had all but vanished, resulting in a form of language — the feuilleton — shorn of both the imaginative quality of the former as well as the sober objectivity of the latter. ${ }^{20}$ In many ways, Kraus views the journalist as the most salient representative of that insidious feature of modernity that collapses all distinctions into sameness and dilutes all substantial thought into the commodified, exchangeable "opinion." 21 In the language of the journalist, "everything always suits everything, and the inability to find old words is a subtlety if the new ones suit everything." ${ }^{22}$ For Kraus, a direct line can be drawn from Heine's language-and specifically the poems published in Das Buch der Lieder (The Book of Songs), Heine's most popular work- to the contemporary press's empty phrase, which is made exclusively for the day.

Kraus then makes a categorical distinction between polemic and satire, arguing that Heine's polemical writings cannot claim the status of true satire because they are wedded exclusively to the material circumstances and thus the historical moment that occasioned their production, the Stoff ("material") as Kraus calls it, a condition that prevents them from transcending their journalistic essence. ${ }^{23}$ A polemic speaks to this or that particularity, such as Heine's notorious literary feud with August Graf von Platen that dissolved into personal attacks against the latter's alleged homosexuality, but once the immediate moment has passed, its relevance expires and its content reveals itself to be empty of lasting significance. And Kraus adds that "whoever mocks his rival's poverty can come up with no better a joke than: Platen's Oedipus would 'not have been so bitter if the writer had had more to bite on' [wäre nicht so bissig geworden, wenn der Verfasser mehr zu beißen gehabt hätte]. A bad disposition [Gesinnung] can only yield bad jokes." ${ }^{4}$ Simply stated, Heine's polemical-journalistic tendencies have, for Kraus, affected (or infected) his satirical sensibility. By so concluding, Kraus suggests that satire can be divided into its authentic and its inauthentic iterations. The problem is that "Heinism"- especially in its satirical form-has managed to produce a generation of "consequences" who repeat Heine's language and who have thereby turned what Kraus believes should have been an exception into the rule: mechanically repeatable language that both responds to, and in turn creates events that mechanically repeat themselves. In comparing Heine to Goethe, Kraus writes: "The poets of humanity produce chaos over and over again; the poets of society sing 
and lament, bless and blaspheme within the order of the world." ${ }^{5}$ By juxtaposing the more noble "humanity" with the more parochial "society," Kraus vents his suspicion of a mode of satire that ultimately preserves the standing social and political order rather than negating it. Thus in response to the discussions circulating in contemporary Vienna about erecting a monument in Heine's honor, he delivers one of his more devastating verdicts:

With all due respect for Heine's enlightening achievements-so great a satirist that he would be considered unworthy of a monument, he was not. Indeed, he was such a minor satirist that the stupidity [Dummheit] of his era has borne posterity. Certainly, posterity builds a monument for itself that it denies him. But truly it also builds the one that it desires for him. ${ }^{26}$

By ironically supporting the building of this monument, Kraus suggests that his contemporaries are unwittingly commemorating exactly what the "minor satirist" Heine means for Kraus: namely, the figure who inaugurated the very generation that now intends to immortalize him and which Heine himself intended to satirize. A physical monument in Heine's honor is tantamount to an admission that Kraus's day is merely an extension or a repetition of Heine's own, and not a qualitative improvement upon it; accordingly, Kraus sees himself as having inherited Heine's "consequences."

For Kraus, neither Heine's journalistic satire nor his future admirers is able to envision a true Nachwelt or posterity—yet to be defined — evidenced by the "stupidity" of Heine's time that identifies with Heine rather than seeing itself reflected in the object of his satire. Blaming his own contemporaries as much as he does Heine, Kraus aims to expose the hackneyed satirist whose language repeatedly inspires the same ineffectual attempt to critique the very historical moment that it fails to overcome: "What lives with the material, dies before the material." ${ }^{27}$ The "material," however, remains the same. Heine's satire fails, in part, because it remains constitutively bound to a limited audience and a limited object, which we could link to what Evers had earlier called a system of "shared values," or what Reinhard Merkel labeled Tendenzsatire. True satire, Kraus cryptically suggests, lives "with language" and is somehow capable of transcending the moment of its conception.

Two years later Kraus delivered an impassioned speech in front of an audience of 1,500 on the Viennese dramatist Johann Nestroy (1801-1862). Nestroy und die Nachwelt: Zum 50. Todestage, the scholar Kurt Krolop has argued, is both an homage to Nestroy as well as a treatise on the problem of the satirist as such, "whose temporal suffering is a permanent agony." ${ }^{28}$ Kraus's concern is thus with reconciling the satirist's allegedly permanent agony with the demand that he or she respond to the contingencies of his or her particular era. To this end, Kraus writes, implicitly recalling his essay on Heine: 
How did it come to be that such a spirit was buried: it must have been the great content of his satirical thought, and I believe that he continues to poetize. He, Johann Nestroy, cannot tolerate that everything that had displeased him remained intact. Posterity repeats his text and doesn't know him . . . it refutes and confirms the satire through the immortality of that which is material. ${ }^{29}$

Kraus insists that his contemporaries neither understand Nestroy nor embrace the satirical poet within him, and because of this, they can only repeat Nestroy's "text" by proving, even fifty years later, to still be the object of his ridicule. ${ }^{30}$ Nestroy, for Kraus, "keeps on writing," for as long as the seemingly intransigent Stoff of his satire persists - petite bourgeois morality, the decaying aristocracy, tenuous conceptions of freedom, to name a few of Nestroy's frequent targets of ridicule-his satires remain topical: "This is what Vienna in 1912 looks like," Kraus asserts, referring to his contemporaries: "Reality is a senseless exaggeration of all the details that the satire of fifty years ago has left behind." ${ }^{11}$ Nestroy had not only anticipated the phenomenon of Heinism that Kraus addressed earlier on; he had also superseded Heine's more limited critique.

For Kraus, it is precisely because Nestroy was capable of identifying the historical realities that he knew were going to turn into near satires of themselves that they became the objects most worthy of ridicule. False satire, to recall, is not capable of asserting itself against the moment in which it is conceived and is thus subsumed by it unawares. ${ }^{32}$ Conversely, the distinguishing feature of Nestroy's satire is that it is "full of un-timeliness [Inaktualität], a persistent objection against the topical [Zeitgemäßen]." ${ }^{33}$ Because of its tendency to consistently negate, it is both able to transcend the moment of its conception while remaining attuned to the material reality that once served as its "occasion" (Anla $\beta) .{ }^{34}$ True satire, it seems, writes the object of its ridicule to its temporal end, be it a literary form, a political movement, or, as we will see, an entire historical epoch. In its grasp, as one critic writes, "the present disappears and [is] nothing but mask, historical time." 35 The satirist reveals, in other words, the emptiness of the empty phrase, and is able to do this, for Kraus, because he or she sees the ruination before everybody else: "It is haunting how reality precedes my satire. Shadows cast bodies," Kraus writes, suggesting that the satirist's language never ridicules the moment as it is, but always in its state of becoming or having become. ${ }^{36}$ Connecting this essay back to Heine, Kraus implies that Nestroy's multiple audiences are always already implicated in his satire: "Satire lives between the errors, between the one that stands too close and the one that stands too far from it." ${ }^{37}$ While Nestroy's contemporaries (Mitwelt) stood too far from his own satire, Kraus's stand too close to it; but both audiences are addressed by it, while Nestroy's ideal audience, I argue, would be a posterity that does not yet exist.

And yet an inherent tension informs Kraus's simultaneous demand that the satirist 
write against his time, address posterity, and still be able to produce what he calls a "transcription of the times" (Abschrift der Zeit) ${ }^{38}$ without simply repeating the time, rendering him indistinguishable from the very mode of repetition that Kraus had earlier denounced in Heinism. This tension is partially resolved, I suggest, when Kraus highlights the way that Nestroy's dramas mimic the panoply of voices, inflections, and dialects that together comprised the language of mid-nineteenth century Austria. "What Kraus especially praised in Nestroy's art of spectacle [Schauspielkunst] was the turning into language of cadence. Only the cadence could have an effect well after the ephemeral performance of a work by Nestroy." 39 It was not a political position or standpoint in Nestroy that explained its ability to withstand the passage of time-indeed, Kraus berated the press for identifying in Nestroy the incipient spirit of the modern brand of liberalism for which it stood and of which Kraus was highly suspicious ${ }^{40}$ — but rather Nestroy's ability to ventriloquize every voice of his epoch in such a way that their ostensible distinctions revealed themselves, in his plays and Possen, to be insignificant variants of the one-sided, single voice of social and political decay under ridicule: Nestroy as seer and dialectician at once.

This explains why the object of Kraus's satire is, too, the language that mediates the event rather than the event itself. For Kraus, this is the language of the press, since this language serves as the most conspicuous cipher of that condition of modernity Kraus laments: repetition without substantial difference. Kraus, by contrast, attempts to elevate Nestroy's method to the dominant principle of his satire: "I prevent the tenth repetition of the crime [des Frevels], whenever I repeat it myself." ${ }^{41}$ Through his unique employment of repetition, soon to be properly unfolded, Kraus claims to put a definitive end to the "crime," to render it, in the words from earlier, dead, historical time, emptied of any legitimacy. "As if adopting Kierkegaard's redefinition of repetition as a forward-looking counterpart to remembrance, and therefore as something new," Kraus's intent, writes Gilbert Carr, is to "interrupt a numerical series of abuses with their qualitatively new, chastening reprise." ${ }^{42}$ Kraus is thus not concerned with upholding or recovering a system of values from a bygone era, since his satire does not contain a "corrective aim." ${ }^{43}$ Through repetition, rather, Kraus immanently critiques the Stoff of his time, which, after the outbreak of the First World War, became nearly impenetrable: "No idea, whether thought, spoken, or screamed, could be strong enough, no prayer ardent enough to penetrate this matter," he once wrote. ${ }^{44}$

Yet how does Kraus ensure that what he calls his satirical transcription cannot be subsumed back into the endless series of repetitions that preceded it? How does his satire go about negating the material it repeats without thereby identifying too closely with it (as in the case of Heine), and ultimately producing an "unwitting tribute" to it? ${ }^{45}$ And if Kraus's satire accomplishes what it claims to accomplish, how does it counter Canetti's still relevant charge that it reduces everything to one and the same language, "and the fight continues"? These are the questions Kraus implicitly 
addresses in his magnum opus, Die letzten Tage der Menschheit, when he leaves the medium of journalism to which his satire had been predominantly confined.

\section{Absolute Satire}

By 1914, it was no longer fools who rushed in to Kraus's head, but veritable madmen. The war brought with it a new challenge, and Kraus had to find the proper medium with which to confront it, as well as the vitriol "befitting even the world war." ${ }^{46} \mathrm{He}$ opted to oppose the theater of war with what the author and critic Roberto Calasso has called a "theater of repetition." ${ }^{77}$ In his introduction to the significantly abridged English translation of Die letzten Tage, Franz Mautner describes the drama as beginning

with the voice of a newsboy and end[ing] with that of God. The cry of the newsboy resounds in Vienna in June, 1914; the voice of God rings out over a battlefield at the end of World War I, at which point the drama transforms into a modern Walpurgis Night. From Vienna the drama spreads out over the territory of the Austro-Hungarian monarchy, the occupied territories and war zones, and, from the third act on, into Germany, and onward, everywhere, wherever the armies and merchants of the Central Powers had penetrated. ${ }^{48}$

Yet Mautner's description, along with other characterizations of the drama as either a "warning play" (Kurt Krolop) or a "post-Christian tragedy" (Edward Timms), is partially misleading, for Die letzten Tage, written and published between 1915 and 1922, resists easy classification and cannot be reduced to what could be called its content alone. ${ }^{49}$ It contains neither images of battle, nor a cohesive narrative structure that accords with the timeline of the war, nor an uncomplicated use of eschatological language_-God's cry at the end of the text, "I never willed it" (Ich habe es nicht gewollt), is a quote from Kaiser Wilhelm II. The drama furthermore does not adhere to the formal structure of classical tragedy, explicitly renouncing a tragic hero while also placing its own stageability into question: ${ }^{50}$ "The action, running through a hundred scenes and a hundred hells, is improbable, disjointed, and heroless." ${ }^{51}$ In forgoing any attempt to represent the war, the drama allows its characters to speak for themselves, as an estimated half of its lines consist of direct quotations culled from actual sources. ${ }^{52}$ It is a text that indicts, with equal fervor, journalists, politicians, bureaucrats, patriots, doctors, scientists, priests, poets, financiers, optimists, and even, as we will see, grumblers. But Die letzten Tage is more than a satire of the First World War; it is a thorough and self-reflexive engagement with the very tensions immanent in the satirical form that I have described above.

Kraus himself appears only once during the whole drama, or rather, before the drama properly begins. Addressing his readers/audience, he writes: 
The staging of this drama . . . is intended for a theater on Mars. Theatergoers of this world would not be able to stand it . . Its humor is merely the self-reproach of the one who, of sound mind, did not go insane from the thought of having bore witness to these time-things [Zeitdinge]. But apart from the one who exposes the ignominy of such complicity to posterity, nobody else can claim a right to this humor. May the contemporaries [Mitwelt] who have allowed the things that are written here to have actually happened place their right to laugh behind their duty to cry. ${ }^{53}$

The reference to the god of war is not a mere rhetorical flourish, and this declaration defines the satirist's role as Kraus now conceives it: namely, to serve as a witness on the threshold that separates the Mitwelt from the Nachwelt. Kraus's monologue thus takes up where his essay on Nestroy from three years earlier left off, but the stakes of satire have risen. For while Nestroy was still able to "laugh metaphysically," 54 the humor of this text indexes the satirist's own implication in "these time-things" - a crucial point to which I will later return. Equally significant is Kraus's suggestion that laughter is the byproduct of the satire and not its end goal, thereby renouncing a community of laughers. ${ }^{55}$

After the monologue comes to an end, Kraus ceases to speak as Kraus and the dialogic form takes over, in which "news reports stand up as people." ${ }^{56}$ This is a crucial move because it enables Kraus to counter the charge of employing the very language of journalism he so bitterly rejects, a language that presupposes an identifiable authorial voice. ${ }^{57}$ Within the theatrical medium it is not he who speaks, but the press itself that obtains a second life; it becomes clear that it is not journalism as such that Kraus undermines, but rather its medium-transcending language that is both complicit in producing, as well as a product of the historical conditions under scrutiny. Agents of the press were, for Kraus, as culpable for the proliferation of, and support for the war as the corrupt generals and militant bureaucrats working for the Central Powers, since it was their newspapers that kept the war effort alive. What follows is a truncated analysis of the different ways repetition functions as a critical force of negation in Die letzten Tage: as quotation without quotation marks, as scenic reprise, and, most significantly because it is the most distinguishing feature of the text as a whole, through the figure of the Nörgler.

Kraus once insisted that his "linguistic art consists in the omission of quotation marks," 58 and indeed many lines from Die letzten Tage can be traced back to their original speakers. ${ }^{59}$ The celebratory war reportage of Alice Schalek was a frequent target of Kraus's critique of the press, and she is one of the few characters referred to by name in the drama. ${ }^{60}$ In a Fackel gloss entitled "The Schalek advances," ${ }^{61}$ Kraus reproduces in list form a collection of actual quotations from Schalek's reports; in Die letzten Tage, these quotations are shaped into a dialogue between "the Schalek" and an unnamed officer on the southwest front: 
THE SCHALEK: So tell me Lieutenant, if the art of an artist could more intensely or passionately create this spectacle? Those that have stayed at home might, unmoved, call this war the ignominy of the century-I myself even called it that, as long as I sat in the hinterland - those that are here, however, are swept by the fever of experience. Isn't that so, Lieutenant, you're standing in the middle of the war, admit that some of you don't even want the war to end!

THE OFFICER: No, nobody wants that. In fact, everybody wants the war to end. (They hear the sough of shots being fired: Ssss ---)

THE SCHALEK: Sss--! That was a grenade.

THE OFFICER: No, that was shrapnel. Can't you tell the difference?

THE SCHALEK: It is obviously difficult for you to understand that for me the timbres [Tonfarben] are not yet distinguishable ... . ${ }^{62}$

The apogee of the exchange is Schalek's admission that she has difficulty distinguishing between the various timbres of battle, thereby alluding to the perilous path that leads from mishearing to miswriting. Schalek's words are also presented here as a direct extension of the sounds of war; her imitation of the shrapnel alludes to the way she almost reproduces or repeats the war in language, but in such a way that aestheticizes its sounds rather than undermines them. In an earlier scene in the drama, a fellow reporter is astounded at "the way [Schalek] describes the corpses, the details of the smell of decay!" (156), prompting one critic to comment that the "original German here is beschreiben, which can mean 'to describe' or 'to write upon.' This particular verb choice appears more than once in reference to Schalek's descriptions of the dead and wounded, and it seems quite likely that Kraus . . . saw the connotations of describing a war correspondent like Schalek as writing upon corpses." ${ }^{63}$ According to this logic, to reproduce Schalek's own statements in this way could be seen as an attempt to revoke the act of "writing upon" corpses and to turn this language itself into a corpse, or into dead, historical time.

Corpses are invoked throughout the drama, including in one of the many scenes that includes Moriz Benedikt, the editor-in-chief of the Neue Freie Presse from 1908 until his death in 1920 and a consistent object of ridicule in Die Fackel both before and during the war. ${ }^{64}$ In Scenes 27 and 28 of Act I, the Vatican and the editorial office of the NFP appear side by side. From the Vatican intones the voice of the "praying Benedikt," and in the bureaucratic office, that of the "dictating Benedikt." What these figures share in common is a position of influence, a voice heard and respected by many, and a namesake. First the Pope pleads:

- - In the holy name of God, our father and lord in heaven, for the sake of the blessed blood of Jesus, which was the price of human redemption, we summon you, who have been appointed by divine providence to be the ruling powers of the 
war-fighting nations, to finally bring to an end this horrible murder that has been bringing dishonor to Europe for one year. It is the blood of brothers that is being spilled onto the land and into the water .... (190)

The editor then "dictates," the semantic ambiguity of the word deliberate: ${ }^{65}$

- - And the fish, lobsters and spider crabs of the Adriatic have never had it so good as they have it now. In the South Adriatic they feasted on almost the entire crew of the 'Leon Gambetta.' The inhabitants of the Middle Adriatic found their sustenance in those Italians that we could no longer save from the vessel 'Turbine,' and in the North Adriatic the dinner table is sufficiently and consistently set for those inhabitants of the sea. $(191)^{66}$

The contrast between the Pope's desperate plea for peace and the callousness of the press mogul—presented here as a secularized pope — could not be starker, while the satire intensifies when we realize that the press's influence in this regard was visible during an earlier conversation between the "Patriot" and the "Subscriber" (to the $N F P$ ) about the moral superiority of the Austrians vis-à-vis the other warring nations. The Subscriber interjects:

And above all: we're always human, as opposed to [our enemies]! For example, the editorial article in the press had the decency to think about the fish and the sea animals in the Adriatic, which'll now have it good because they'll be able to feast on so many Italian corpses. That, indeed, is humanity carried to the extreme: in these trying times to still be thinking of the sea life in the Adriatic when even humans have to suffer from starvation! (119)

Conspicuously absent in the examples above, or in any of the quotations found in the drama, is any critical intervention apart from the reader's own, necessarily recalling Walter Benjamin's juridical-theological theory of quotation as elaborated in his 1931 essay "Karl Kraus." Benjamin writes that quotation, which empties language of its subjective intention ("destroyed" or "punished" in his terminology) once it is placed into a new context ("saved" or returned to its "origin"), constitutes Kraus's singular critical procedure. ${ }^{67}$ Reactivating his theory of language from his earlier writings, Benjamin argues here that Krausian quotation unites the fundamental polarities immanent in all "fallen" language: "rhyme" and "name." Quotation "rhymes" insofar as it produces an exact repetition of the quoted language; it rhymes with itself and therefore qualifies as the self-referential dimension of language, or that moment which draws language inward. In its naming function, by contrast, quotation taps into the potential in language to reach beyond its linguistic constitution and establish a relation 
to the nonlinguistic world. The quotation names the instantiation of language being quoted by turning it into a thing of the past: a "ruin." 68 If then, as Werner Hamacher suggests, all language in Benjamin's schema is affected by an "ironic-allegorical" character, in that it never means what it says, then Krausian quotation divests it of this character by bringing both of these semantic components (rhyme and name) to the fore and revealing nothing but their disjunction. ${ }^{69}$ In this way, the dramatic use of quotation, I would suggest, is the apotheosis of immanent critique as it functions in Kraus, for by tracing its object completely, it leaves no remainder. Quotation does away with the external interpretation that normally mediates the relationship between an object of criticism and the critique itself, an interpretation that necessarily implies a fixed position from which it derives its authority (recall: Tendenzsatire). In Die letzten Tage, the only external move vis-à-vis quotation is the dialogic, performative element that summons the quotation to life in each character in order to immediately render it "nothing but mask, historical time." Schalek's statements, which she herself has repeated several times before, are no longer embedded in her own narrative of the war, nor even in the fabric of Kraus's essays from Die Fackel; Moriz Benedikt's words are brought to bear against the Pope's alone.

Repetition also functions in Die letzten Tage on the level of its formal structure. Scenes indeed repeat one another almost verbatim throughout the entire text, from the newsboy yelling variations of "extra, extra!" at the beginning of each act to the recurring conversations between the "Patriot" and the "Subscriber." Krolop has thus rightly characterized the internal temporal structure of the play "not as a temporal development [Zeitentwicklung], but as time-space [Zeitraum] that is without 'origin' and without future," implying that the reprisal of scenes mimics one of the war's most brutal features: its mechanical repetition, an extension of Kraus's bleak vision of modernity. ${ }^{70}$ The last scene of the Prologue and its reprise in Scene 52, Act V provide an illustrative example of this textual practice. The Prologue takes place at the funeral of Franz Ferdinand and his wife; those in attendance include the Court Councilor Nepalleck, "a delegation of local councils," two functionaries, a doctor, a woman in distress, and of course, an editorial journalist. Every dignitary present expresses remorse and tries to justify his or her attendance by insisting on his or her own social worth, until the pretense of solemnity is interrupted by the tautological utterance of the two council members, Stein and Hein: "Indeed, I know not what my business here is, but since I'm now here, here I am now" (64). As the scene progresses, the attendees' statements become more and more absurd: the two consuls, for example, admit "we indeed do not have any relationship with the recently deceased worth mentioning, but we have nevertheless come running here to fulfill our duty," and the presence of the art dealers and book handlers appears equally suspicious. As the funeral procession turns to prayer, the scene abruptly ends with the editor 
(presumably based on the figure of Benedikt) commanding his journalist to report on the scene: "Write down how they're praying!" (60-66).

A near replica of the scene is rehearsed toward the end of the final act, set this time at the Nordbahnhof during the last days of the war. The stage direction reads: "A train carrying the disabled veterans to be replaced [Austauschinvaliden] has just arrived. Bodies on stretchers that are convulsing are being loaded out of the railway cars. The stretchers are disposed" (666). The shoal of dignitaries has reappeared, each repeating a truncated version of his or her previous reason for having attended the funeral of the Archduke and Duchess four years earlier. The minor difference is revealed at the very end, when the editor-in-chief, once again, commands his journalist to "write down how they're eavesdropping!", forming a parallel between the disingenuous prayer from earlier and the communicative act of eavesdropping (669). The war in nuce appears to be wedged between the two statements of the editor, the one that commences the play's action and the one that signals its imminent end. The difference between these two scenes, which cover a span of four years, lies in the mere alteration of one word. The scenic reprise in this way mimics the repetition of war, foreclosing any possibility of reaching a moment beyond repetition.

This is why the Nörgler, the drama's resident satirist whose conversations with the "Optimist" punctuate the play from beginning to end, plays such a crucial role in terms of the structure of the drama: it is the beyond that is his province alone. If, to recall, for Bogel, the "shadow of connection" between the satirist and his or her object of ridicule informs the structure of satire despite the satirist's implicit claim to the contrary, in the case of the Nörgler, such identification with this object-namely, the business of war-as well as with the audience is already presupposed. Oscillating between his dual function as commentator on, and participant in the events of the drama, the Nörgler can never fully claim to possess the sole, uncontaminated voice of reason that less radical forms of satire take as a given. Using a metaphor that accurately describes his own predicament, the Nörgler tells the Optimist that it is impossible to light a match (let alone a "torch") when the entire world is burning:

THE OPTIMIST (wants to light a cigarette): Strange, no match is catching fire. THE GRUMBLER: That's a result of the ultimatum on Serbia.

THE OPTIMIST: I said that no match is catching fire!

THE GRUMBLER: And I'm saying that's because we've succeeded in setting the world ablaze! (658-59)

The Nörgler, I argue, is not simply Kraus, as some critics have suggested, but, rather, the drama's final instance of repetition, as it is he who quotes not only the other figures in the drama but also from the Fackel-Kraus's essays and aphorisms, rendering Kraus 
himself a repeatable figure. ${ }^{71}$ The Nörgler is the last "victim" required in order to make the satire absolute; in his own terms, he is merely another "noise" of war despite his seeming ability to see through its brutality and from this vantage point derive a position of authority. His last monologue is quite telling in this regard:

I have taken the tragedy, which disintegrates into scenes of disintegrating humanity, on myself, so that it might be heard by the spirit who takes pity on the victims, even though he may have renounced for all time his connection with a human ear. May he receive the keynote of this age, the echo of my bloodstained madness, through which I share the guilt for these noises. ${ }^{72}$ May he accept it as redemption! ${ }^{73}$ (681)

Making a final plea to the "spirit" watching from the temporal beyond, the Nörgler's own tragedy is constituted by his position as a marginal figure who, in refusing to purely speculate (or, like the journalist, "describe" the events that transpire), is consumed in the end by his satirical method-the "keynote" of the era is the echo of his "bloodstained madness," not the reverse. ${ }^{74}$ The only difference between him and the other figures is that he is conscious of his guilt, whereas they are not: that they become sacrifices without ever acknowledging their guilt constitutes their tragedy. ${ }^{75}$ It is thus through the split within the Nörgler's function that all distinctions between satirist, audience and object of ridicule ultimately collapse: "because this drama has no other hero besides mankind, it has no audience!" (671), he claims, pointing, once again, to his implicated Mitwelt. At once engulfed by the war and imitating its destructive essence through his own violent language, the Nörgler effectively renounces the totality of his historical moment, including the very legitimacy of his role in the drama as commentator.

And yet, the Nörgler's language often bespeaks a curious admixture of hope and despair, evidenced above all in one of his final pledges to posterity: "I am preserving documents for an era that will no longer understand them, or will live so far from today that it will declare me a forger. Yet no: the time to say this will never come. For it will not be" (671). Filled with regret over his impotence in the face of such an overwhelming power, the Nörgler still allows for the possibility that in time, his satire will be deemed a forgery by an audience that fails to comprehend its contents-here the Nörgler speaks as the "aggrieved idealist" about an uncontaminated posterity he can only envision. ${ }^{76}$ Such an imagined temporal beyond, I suggest, conditions and anchors the Nörgler's position; it is the only possible counter image to which he can allude, and what it looks like must necessarily remain unspoken. ${ }^{77}$ But the "yet no" (doch nein) in the quote above places this vision once again in check by denying that such a moment and its concomitant audience will ever come to be. The Nörgler's greatest fear is that the war and everything it consists of will never end, that his Mitwelt, in other words, will never become a Nachwelt. He expresses as much in the same scene: 
THE OPTIMIST: But when peace finally comes-

THE GRUMBLER:- then will the war begin!

THE OPTIMIST: Every war has ended by means of a peace.

THE GRUMBLER: Not this one ... The world will founder, and nobody will know. Everything that was yesterday will have been forgotten, that today is, not seen, that tomorrow brings, not feared. We will have forgotten that we lost the war, forgotten that we began it, forgotten that we waged it. It will, therefore, never come to an end. $(659)^{78}$

Structurally speaking, if the war never ends, neither will the satire. ${ }^{79}$ The Nörgler's essential paradox thus consists in the fact that he longs for a moment in which his satire would be deemed unintelligible, since merely to recognize it means to be somehow implicated in it. Yet in order to know that one has arrived at such a moment, one must also recall the event that had once been the object of satire, since not to remember could also be taken as a sign that one has not moved, as it were, beyond repetition, that one is still being addressed by the satire in question. A productive if unresolved tension in the Nörgler's function, this predicament makes explicit one of the central questions that the drama poses to its interpreters: at what point can the Mitwelt rightfully claim that it has become the Nachwelt? Standing at the threshold between these two worlds, the Nörgler believes he is writing a text that will never end, while he nonetheless hopes to be proven wrong. This is how to best understand Helmut Arntzen's claim that satire is, for the Nörgler, "after its own self-cancellation [Aufhebung]." 80

The paradox above is perhaps best illustrated in Act IV, Scene 29, in which the Nörgler and the Optimist are discussing an infamous postcard that displays a photograph of the Italian politician, Cesare Battisti, recently hanged, and next to him, his gleeful executioners. The photo, it should be noted, also serves as the frontispiece to the drama. "For it is not just that he was hanged," the Nörgler says,

but also that the photograph itself was taken; and it was not just the executioners that were photographed, but also those standing by to observe, and yes, even the photographers. And the singular effect of our atrocity is now that the enemy's propaganda-which, instead of lying has simply reproduced our truths-do not even have to photograph our deeds, because, to its befuddlement, our own photographs of our own deeds are already to be found at the scene of the crime... For it is not simply that [the criminal] killed, nor that he photographed the killing, but that he photographed himself along with the killing; and that while taking the photograph he photographed himself along with his crime [und daß er sich photographierend mitphotographiert hat]—that turns his type into an unfading photograph [unvergänglichen Lichtbild] of our culture. As if what we had done would not speak for itself! $(510)^{81}$ 
For the Nörgler, the photograph provides an image of the concentric circles of ideology fueling the war. At the center stands the deed of execution, which he finds reprehensible enough. But even worse are the grinning perpetrators who surround the victim; worse than that is their pose for the camera; and worse than that are the photograph and the photographer that capture the entire scene-and then there is the Nörgler holding the photograph. In one final repetition the image reappears as one of the last "apparitions" just prior to the drama's convulsive epilogue, "Die letzte Nacht" ("The last Night"). ${ }^{82}$ These truths, the Nörgler concludes, are the real lies, and their effect is greater than the more conventional lies told by the enemy nations, a recurring motif in his monologues throughout the drama.

But it is also useful to imagine this "unfading" photograph as representing the satirist himself, in that it preserves an image for posterity of that which threatens to be forgotten. ${ }^{83}$ The inability to intervene in, or provide a corrective to the madness is compensated by the vanishing but nonetheless residual plea that the photograph be seen by a future generation. The photo thus reiterates the paradox just elaborated, insofar as the true posterity that the Nörgler anticipates would be one for which this photograph, too, had become unintelligible; such an audience would understand neither the crime portrayed nor its photographic reproduction, because the conditions that perpetually demand to be satirized would have disappeared. For the Nörgler, posterity can only emerge once repetition has been brought to an end, once the moment being critiqued can be viewed as a singular moment, wholly severed off from the moment that succeeds it. ${ }^{84}$ In this way, the Nörgler's absolute satire offers a critique in whose clutches nobody is absolved. Recalling my opening sentiments, it functions by negating the entire language of the present- “for analogous to Adorno's dictum: there is no correct speech amidst falsehood [es gibt kein richtiges Sprechen im falschen]"85_if only to show that this language is, indeed, a false one.

At the end of Nestroy und die Nachwelt, Kraus claims for satire a singular status among other art forms, since it is "the art that, before all others, survives both itself as well as the dead time ... The satirical artist stands at the end of a development that has denied itself to art. He is its product and its hopeless antipode. He organizes the escape of spirit before humanity; he is the concentration in reverse [Rückwärtskonzentrierung]. After him, the deluge." 86 With this, Kraus partially anticipates the substance of the "satiric tragedy" 87 he began to compose three years later, comprised of an apocalyptic deluge of sounds and voices that together constitute the "dead time." But Die letzten Tage takes Kraus's theory of satire one step further, for in it there is no room left even for the satirist to take a stand external to, or at the end of the temporal "development" that it envisions, given that the end of such a development is precisely what is being placed into question. In its purest form, Kraus's absolute satire has allegiance neither to an audience nor to a predetermined position that would claim to be untouched by that which it aims to negate. And yet it does not negate for 
the sake of negation alone, as Canetti intimated earlier, but is, rather, conditioned and driven by the quasi-utopian moment that has yet to come, that is, by posterity, which would render absolute satire obsolete.

Cornell University

\section{Notes}

1. I would like to thank the German Studies Association for giving young scholars like myself the opportunity to share our work with colleagues. I would also like to thank my adviser, Patrizia McBride, for all of her guidance and support, and my friends and colleagues-especially Anna Horakova, Carl Gelderloos, and Paul Flaig-for reading multiple drafts of this paper and seeing it through to its final form.

2. The German word Proze $\beta$ also refers to a court of law, suggesting a structural affinity between Kraus's satirical practice and the execution of justice. See Elias Canetti, "The New Karl Kraus (Speech Given at the Berlin Academy of the Arts)," in The Conscience of Words, trans. Joachim Neugroschel (New York: Continuum, 1979), 216.

3. On Canetti's unique position as an observer and critic of Kraus, Dietmar Goltschnigg and Hartmut Steinecke have written, "No other contemporary witness described the formidable, irresistible effect that Kraus used to exert on his readership and audience. . ." See Dietmar Goltschnigg and Hartmut Steinecke, eds., Heine und die Nachwelt: Geschichte seiner Wirkung in den deutschsprachigen Ländern: Texte und Kontexte, Analysen und Kommentare, Band 2: 1907-1956 (Berlin: Erich Schmidt, 2008), 51.

4. Die Fackel was the satirical journal that Kraus published from 1899 until his death in 1936. From 1911 onwards, Kraus was the sole contributor to the journal.

5. Canetti, "The New Karl Kraus," 216.

6. In the paralipomena to Walter Benjamin's essay "Karl Kraus," Benjamin compares the eponymous satirist to the ever-ironic Mephistopheles in Goethe's Faust: "Ich bin der Geist, der stets verneint." See Walter Benjamin, Gesammelte Schriften II, Vol. 3 (Frankfurt am Main: Suhrkamp, 1980), 1091.

7. M. H. Abrams and Geoffrey Galt Harpham, A Glossary of Literary Terms: Eighth Edition (Boston: Thomson Wadsworth, 2005), 284-85.

8. Frederic Bogel, The Difference Satire Makes: Rhetoric and Reading from Jonson to Byron (Ithaca, NY: Cornell University Press, 2001), 68.

9. Kraus gave over seven hundred public readings in his lifetime, many of which left a lasting —and ultimately damning -impression on Canetti, who reflected: "It took me decades to realize that Karl Kraus had succeeded in forming a hunting pack of intelligentsia — gathering at every lecture and existing acutely until the victim was brought down." See Canetti, "Karl Kraus, The School of Resistance," Conscience, 31.

10. Kai Evers, "Destructive Satires: Canetti and Benjamin's Search for the Murderous Substance of Satire," in The Worlds of Elias Canetti: Centenary Essays, eds. Julian Preece and Bill Donahue (Cambridge: Cambridge Scholars Publishing, 2007), 208.

11. See Reinhard Merkel, Strafrecht und Satire im Werk von Karl Kraus (Frankfurt am Main: Suhrkamp, 1998), 130.

12. The term "speculation" needs to be further qualified, since as a satirist fully submerged in his historical moment, namely the period from fin-de-siècle Vienna through the rise of Hitler, Kraus, as Roberto Calasso has pointed out, "never theorized about the [First World War] or, strictly speaking, about anything else ... he completely lacked speculative detachment." His explicit renunciation of any "speculative detachment" is, indeed, what necessitates the term "absolute satire." See Roberto Calasso, The Forty-Nine Steps, trans. John Shepley (Minneapolis: University of Minnesota Press, 2001), 97. 
13. Discussing the scope and far-reaching implications of Kraus's work, Hermann Broch wrote: "Absolute satire made its first full appearance, necessarily, where the European value vacuum had reached its maximum-in Austria." See Broch, Hugo von Hofmannsthal and his Time: The European Imagination, 1860-1920, trans. Michael P. Steinberg (Chicago: University of Chicago Press, 1984), 180.

14. I am alluding here to G.W.F. Hegel's dismissal of certain contemporaries for whom "in the absolute everything is the same," and thus whose cognition is "naively reduced to vacuity" in its inability to make distinctions. See Hegel's Phenomenology of Spirit, trans. A. V. Miller (Oxford: Oxford University Press, 1977), 9.

15. See, for example, Adorno's short essay "Die Wunde Heine," which is in many respects hardly more than an abridged version of Kraus's earlier essay, if indeed it foregrounds more explicitly the relationship between Heine's assimilatory strivings and the conciliatory tone of his language. Theodor Adorno, "Die Wunde Heine," in Noten zur Literatur (Frankfurt am Main: Suhrkamp, 2003), 95-100.

16. See Bernd Witte, "Feuilletonismus: Benjamin, Kraus, Heine," in Walter Benjamin und das Wiener Judentum zwischen 1900 und 1938, eds. Sascha Kirchner, Vivian Liska, Karl Solibakke, and Bernd Witte (Würzburg: Königshausen \& Neumann, 2009), 31.

17. To limit the thematic scope of this article, I will not delve into the detail that this discourse warrants. For recent engagements with Kraus's place within the larger trajectory of Heine reception, see Paul Peters, "Barbarei in der Kultur: Karl Kraus und die Folgen," in Die Wunde Heine: zur Geschichte des Heine-Bildes in Deutschland (Bodenheim: Philo, 1997), 119-53; Dietmar Goltschnigg, Die Fackel ins Wunde Herz: Kraus über Heine: Eine “Erledigung”? Texte, Analysen, Kommentar (Vienna: Passagen, 2000); and Dietmar Goltschnigg and Hartmut Steinecke, eds., Heine und die Nachwelt (Berlin: Erich Schmidt: 2008), 43-57. Peters is especially explicit in arguing that Kraus's attacks on Heine's are only thinly veiled expressions of his Jewish self-hatred. See Peters, 124.

18. Karl Kraus, "Heine und die Folgen,” Die Fackel 13, nos. 329/330 (August 1911): 19, http:// corpus1.aac.ac.at/fackel/. All translations of Kraus are my own unless otherwise indicated.

19. The position I follow most closely in this regard, and the most recent and thorough engagement with Kraus's "Jewish self-fashioning" and his relationship to contemporary, assimilated Jewish writers and thinkers can be found in Paul Reitter, The Anti-Journalist: Karl Kraus and Jewish Self-Fashioning in Fin-de-Siècle Europe (Chicago: University of Chicago Press, 2008). For a recent engagement specifically with the discourse of "Jewish self-hatred," see Reitter, On the Origins of Jewish Self-Hatred (Princeton: Princeton University Press, 2012).

20. See Edward Timms, Karl Kraus, Apocalyptic Satirist: The Post-War Crisis and the Rise of the Swastika (New Haven, CT: Yale University Press, 2005), 349.

21. Benjamin writes that the journalist's opinion is, for Kraus, "false subjectivity that can be separated from the person and incorporated in the circulation of commodities." The term "opinion" (Meinung) is consistently ridiculed in Kraus's oeuvre. See Walter Benjamin, "Karl Kraus," trans. Edmund Jephcott, in Selected Writings: Volume 2, part 2, 1931-1934, eds. Michael Jennings, Howard Eiland, and Gary Smith (Cambridge: Belknap Press, 2005), 439.

22. Kraus, "Heine," 12.

23. The late Kraus scholar Irina Djassemy has, too, made a crucial distinction between polemic and satire, defining the former as a critique of a specific text or an individual, and the latter as a critique against a general condition. See Djassemy, Der "Productivgehalt Kritischer Zerstörerarbeit": Kulturkritik bei Karl Kraus und Theodor W. Adorno (Würzburg: Königshausen \& Neumann, 2002), 135.

24. Kraus, "Heine," 26. For a thorough engagement with Heine's long-standing feud with August Graf von Platen — and the striking parallels between Heine's and Kraus's literary polemics—see Andreas Stuhlmann, "Die Literatur-das sind wir und unsere Feinde": Literarische Polemik bei Heinrich Heine und Karl Kraus (Würzburg: Königshausen \& Neumann, 2010), 59-156. 
25. Kraus, "Heine," 19. One might say that for Kraus it is not the poets that should be banned from the republic, but rather the bad poets.

26. Kraus, "Heine," 31.

27. Kraus, "Heine," 14. Kraus, it should be noted, actually praises Heine's Romanzero, adding rather snidely, however, "Heine needed the experience of dying in order to become a poet." See Kraus, "Heine," 28.

28. See Kurt Krolop, Sprachsatire als Zeitsatire bei Karl Kraus: Neun Studien (Berlin: Akademie, 1987), 37.

29. Karl Kraus, "Nestroy und die Nachwelt: Zum 50. Todestage," Die Fackel 14, nos. 349/350 (May 1912): 3, http://corpus1.aac.ac.at/fackel/.

30. For a comprehensive (if not recent) overview of Kraus's appropriation of Nestroy in Die Fackel, of the latter's reception in early twentieth century Vienna, and of the relationship between Kraus and Nestroy's satirical Sprachkunst, see Helmut Rössler, Karl Kraus und Nestroy: Kritik und Verarbeitung (Stuttgart: Akademischer Verlag, 1981).

31. Kraus, "Nestroy," 20.

32. In Adorno's terms, such satire is blind to the actual "difference between ideology and reality" that it therefore cannot illuminate. Writing after the Second World War, Adorno believes satire has run its course, for it can no longer rely on the implicit appeal to self-evidence that once imbued it with authority. The gap between reality and ideology, as stated above, has closed. Adorno errs, however, in conflating the terms "satire" and "irony," which ought to be kept apart. See Theodor Adorno, "Juvenal's Error," trans. E.F.N. Jephcott, Minima Moralia: Reflections on a Damaged Life (London: Verso, 2005), 211.

33. Kraus, "Nestroy," 16.

34. Seeing in Nestroy a precursor to himself, Kraus writes of his own work in a similar way: "My readers believe that I write for the day because I write from the day. I must thus wait until my things (meine Sachen) have aged. Only then will they possibly acquire their timeliness (Aktualität)." See Kraus, "Tagebuch,” Die Fackel 10, no. 256 (June 1908): 15, http://corpus1.aac.ac.at/fackel/. Alfred Pfabigan also writes that Kraus "had repeatedly insisted that one would only recognize the true value of his work once the ridiculous contingent occurrences had disappeared from the collective memory.” See Pfabigan, “'Orgien im Gemeindebau': Der Herr Karl als Zeitgenossen," in Österreich (1945-2000): Das Land der Satire, eds. Jeanne Benay and Gerald Stieg (Bern: Lang, 2002), 59.

35. Wilhelm Hindemith, Die Tragödie des Nörglers: Studien zu Karl Kraus' Moderner Tragödie "Die Letzten Tage Der Menschheit" (Frankfurt am Main: Lang, 1985), 62.

36. Kraus, "Der Untergang der Welt durch schwarze Magie," Die Fackel 14, no. 363 (December 1912): 26, http://corpus1.aac.ac.at/fackel/. Roberto Calasso similarly writes that Kraus is able to express "that coming-to-itself [of society]" better than any of his contemporaries, including Brecht. See Calasso, Forty-Nine Steps, 228.

37. Kraus, "Nestroy," 22.

38. Kraus, "Im dreißigsten Kriegsjahr," Die Fackel 30, no. 800 (February 1912): 2, http://corpus1.aac .ac.at/fackel/.

39. Rössler, Karl Kraus und Nestroy, 157.

40. Kraus, "Nestroy," 19.

41. Kraus, "Antworten des Herausgebers," Die Fackel 6, no. 164 (June 1904): 22, http://corpus1.aac .ac.at/fackel/.

42. See Gilbert Carr, "Figures of Repetition: Continuity and Discontinuity in Karl Kraus's Satire," The Modern Language Review 102, no. 3 (2007): 773.

43. Hutcheon sees the "corrective aim of satire's scornful ridicule" as "central to its identity." See Linda Hutcheon, A Theory of Parody: The Teachings of Twentieth-Century Art Forms (Champaign: University of Illinois Press, 2000), 56. 
44. I am taking this from Canetti's "Der neue Karl Kraus," who is citing Kraus's diary entry. See Canetti, 356.

45. Bogel, The Difference Satire Makes, 74.

46. Canetti, "The New Karl Kraus," 217.

47. Calasso, Forty-Nine Steps, 106.

48. See Franz Mautner's “Critical Analysis,” in The Last Days of Mankind, trans. Sue Gode, ed. Frederick Ungar (New York: F. Ungar, 1974), 239.

49. Calasso similarly writes that Die letzten Tage "is not an early example of 'documentary theater' or 'epic theater' or 'political theater' or 'theater of the absurd,' to cite the paltry labels that people have sought to apply this work (and it is not hard to apply them, at the cost, of course, of losing the essential)." See Calasso, Forty-Nine Steps, 93.

50. Djassemy points out that "the following elements remain from the conventional tragedy: the division into five acts, the necessity of the fateful occurrences, the numerous sacrificial deaths, and the collapse (Zusammenbruch) as the conclusion.” See Irina Djassemy, Die verfolgende Unschuld: zur Geschichte des autoritären Charakters in der Darstellung von Karl Kraus (Vienna: Böhlau, 2011), 115.

51. This translation is from Max Knight and Joseph Fabry, In These Great Times: A Karl Kraus Reader," ed. Harry Zohn (Chicago: University of Chicago Press, 1984), 159.

52. Eckart Früh has shown, for example, that at least forty scenes in the drama "are based wholly or in part on material from the Arbeiter-Zeitung," the organ of the Austrian Social Democratic Party, which, until 1917, reflected the nationalistic views of the party's right-wing faction. See Eckart Früh, “Die 'Arbeiter-Zeitung' als Quelle für 'Die letzten Tage der Menschheit,'” in Karl Kraus in neuer Sicht: Londoner Kraus-Symposium, eds. Sigurd Paul Scheichl and Edward Timms (Munich: Edition + Text, 1986), 209-34.

53. Kraus, Die letzten Tage der Menschheit: Tragödie in fünf Akten mit Vorspiel und Epilog (Frankfurt am Main: Surhkamp, 9), 1986.

54. Kraus, "Nestroy," 23.

55. Benjamin, too, believed Kraus "was at pains from the first to distinguish the genuine satirist from the scribblers who make a trade of mockery and who, in their invectives, have little more in mind than giving the public something to laugh about." See Benjamin, "Karl Kraus," 448.

56. Knight and Fabry, In These Great Times, 159.

57. I am referring here primarily to Witte's comment from earlier. See footnote 16.

58. Kraus, "Im dreßigsten Kriegsjahr," 2.

59. My emphasis.

60. Timothy Youker writes: “The play's treatment of one particular journalist, Alice Schalek, Austria's first female professional war correspondent, who appears in a total of seven scenes, provides a useful example of Kraus's contempt for war journalism." See Timothy Youker, "'The Sound of Deeds': Karl Kraus and Acoustic Quotation,” Theatre Journal 63, no. 1 (March 2011): 85-100.

61. Kraus, "Die Schalek dringt weiter vor," Die Fackel 17, no. 406 (October 1918): 17-19, http:// corpus1.aac.ac.at/fackel/.

62. Kraus, Die letzten Tage, 189.

63. Youker, “'The Sound of Deeds,"” 89.

64. The editor and proprietor Benedikt appears in Die Fackel as early as 1899, the journal's founding year. For more on Kraus's notorious relationship to Benedikt, see Timms, Apocalyptic Satirist, 87-89, or Reitter, Anti-Journalist, 86-88.

65. Erich Heller writes that Kraus's "single word" is "precise through its infinite ambiguity." See Erich Heller, "Karl Kraus: Satirist in the Modern World," in The Disinherited Mind: Essays on Modern German Literature and Thought (New York: Barnes \& Noble, 1971), 239.

66. In Die Fackel, Kraus juxtaposes the two statements in two adjacent columns, the first under the title "Benedikts Gebet," the second, "Benedikts Diktat." See Karl Kraus, "Zwei Stimmen,” Die 
Fackel 17, no. 406 (October 1915): 1, http://corpus1.aac.ac.at/fackel/. Otherwise, they are the same.

67. See Benjamin, "Karl Kraus," 453-54. Alexander Gelley has written that in this essay, Benjamin is concerned with identifying the "potential of citation to pierce through layers of intention, deception, and ambiguity and draw out of the fabric of language a power of judgment." See Alexander Gelley, "Epigones in the House of Language," Partial Answers: Journal of Literature and the History of Ideas 5, no. 1 (2007): 29.

68. In the introduction to his translation of Adorno's dissertation on Kierkegaard, Robert Hullot-Kentor lucidly explains the significance of the allegorical artwork-qua-ruin: "[Art]works are not studied in the interest of returning them to their own time and period, documents of 'how it really was,' but rather according to the truth they release in their own process of disintegration." See Robert Hullot-Kentor, forward to Kierkegaard: Construction of the Aesthetic (Minneapolis: University of Minnesota Press, 1989), xv.

69. See Werner Hamacher, "The Word Wolke," in Benjamin's Ground: New Readings of Walter Benjamin, ed. Rainer Nägele (Detroit: Wayne State University Press, 1988), 163.

70. Krolop, Sprachsatire, 66.

71. Karl Riha, for example, writes: "In the figure of the 'Nörgler' the author himself comes forth to speak, the Fackel-Kraus, who takes the language and the speech of the time by its word." See Karl Riha, Kritik, Satire, Parodie (Opladen: Westdeutscher Verlag, 1992), 138.

72. My emphasis. The repetition in the Nörgler's language evokes comparisons to Georg Büchner, and commentators have pointed out that more than just stylistic devices connect the two authors. Krolop, for example, draws attention to both authors' critique of misused language that has been saturated in ideology. For more, see Krolop, Sprachsatire, 125.

73. This is the translation offered in the English version of Benjamin's essay on Karl Kraus. See Benjamin, "Karl Kraus," 444.

74. Calasso makes a similar claim: "Kraus does not want to remove himself from guilt; he is not seeking a paradise of origins nor one of postrevolution, and his inflexible immobility has a strength that criticism leaves intact.” Though, as I will soon suggest, Kraus is, indeed, seeking something beyond the admission of his complicity. See Calasso, Forty-Nine Steps, 224.

75. Hence the statement: "It is not lamentable that human sacrifices had to perish in unheard of quantities because a foreign will drove them to the slaughter bench, but tragic because they had to atone for an unknown." See Kraus, Die letzten Tage, 224.

76. Kurt Tucholsky, an admirer of Kraus, wrote that the satirist "is an aggrieved (gekränkter) idealist: he wills the world to be good; it is bad, and thus he attacks the bad." See Kurt Tucholsky, "Was darf die Satire," Gesammelte Werke 2: 1919-1920 (Hamburg: Rowohlt, 1985), 43.

77. Here I refer to Wolfgang Preisendanz, who argues regarding the satirical, "the potentiality of the non-a does not commit itself to a definitive counter-imaginary (Gegenbildlichkeit)." In this context, the Nörgler's "non-a" is clearly yet to be defined. See Wolfgang Preisendanz, "Negativität und Positivität im Satirischen," Poetik und Hermeneutik, Bd. 7, Das Komische (Munich: Fink, 1976), 414.

78. Calasso provocatively echoes the Nörgler's prescience by writing: "before Nazism existed, even only as a name, Kraus wrote the most precise description of Nazism to appear in the German language." See Calasso, Forty-Nine Steps, 106.

79. Kraus's "Im dreißigsten Kriegsjahr," written in 1929, most likely alluded to/commemorated three events: the thirtieth anniversary of Die Fackel, the metaphorical war that Kraus had been waging during the journal's entire span of existence, and the Thirty Years War. See Kraus, "Im dreißigsten Kriegsjahr," 1.

80. See Helmut Arntzen, Literatur im Zeitalter der Information: Aufsätze, Essays, Glossen (Frankfurt am Main: Athenäum, 1971), 166.

81. Commenting on this particular scene, Djassemy writes: "Battisti's executioner becomes in this way 
the prototype of the irrational, tautological, and self-stylized 'native' (Bodenstädigen) uninhibited by scruples of conscience. He sets himself up as an object and treats the others like objects as well . ..." Djassemy, Die verfolgende Unschuld, 165.

82. The stage direction reads, "Feverishly distorted wine tavern music (Heurigenmusik) begins. Battisti's execution. Laughing soldiers stand around the corpse, the curious stretch their necks. Hands above the head of the dead, the jolly executioner," followed by the appearance of "the Austrian countenance." Kraus, Die letzten Tage, 723.

83. This resonates with what Roland Barthes says about the photograph, whose effect "is not to restore what has been abolished (by time, by distance) but to attest to what I see has indeed existed." See Roland Barthes, Camera Lucida, trans. Richard Howard (New York: Hill and Wang, 1981), 82.

84. See Gilles Deleuze, Difference and Repetition, trans. Paul Patton (New York: Columbia University Press, 1994), 10.

85. See Helmut Arntzen, "Einige Dialogstrukturen in Karl Kraus' Drama 'Die letzten Tage der Menschheit," Sprachspiel und Bedeutung: Festschrift für Franz Hundsnurscher zum 65. Geburtstag (Tübingen: Niemeyer, 2000), 435.

86. Kraus, "Nestroy," 23.

87. This is Mautner's term for the drama. See Mautner, "Critical Analysis," 239. 